\title{
Stakeholder Prioritization, Strategic Corporate Social Responsibility and \\ Company Performance: further evidence
}

\author{
Giacomo Boesso \\ (University of Padova) \\ Francesco Favotto \\ (University of Padova) \\ Giovanna Michelon \\ (University of Exeter and of Padova)
}

\begin{abstract}
Using KLD data on more than 900 company's performance over a nine year period in seven areas of corporate social responsibility (environment, community, corporate governance, diversity, employee relations, human rights, and product quality), this research note re-tests Michelon et al. (2013) proxies for prioritization and strategic approaches to CSR. The results show that, when a company pursues CSR initiatives that are linked to stakeholder preferences and allocates resources to these initiatives in a strategic way, the positive effect of its CSR initiatives on financial Corporate Performance (CP) strengthen. The analysis of KLDs' variance and top tiers is thus proposed as a parsimonious way to measure when companies link their CSR initiatives to salient stakeholder preferences and undertake the corporate social actions that are ultimately relevant to the company's strategy and financials.
\end{abstract}

Keywords: Stakeholder management, corporate social responsibility, prioritization and strategic CSR, performance 


\section{Introduction}

The link between corporate social responsibility (CSR) and company financial performance $(\mathrm{CP})$ has gained the attention of academics for a very long time, across different disciplines and methods. In their seminal work, Porter and Kramer (2006) proposed that the economic objectives of the firm and the objectives of CSR initiatives do not need to separate and distinct. Instead of focusing on the "tension between business and society," companies should understand the interdependence between the two and anchor CSR initiatives in their company-specific strategies and activities.

Following this framework, Michelon et al. (2013) empirically examined whether CSR initiatives have a greater impact on company financial performance if the company prioritizes its CSR initiatives and channels resources to these initiatives in a strategic way than if it approaches CSR based on generic rationales that all stakeholder initiatives are equally preferable and targetable. Their analysis, based on a sample of 188 best corporate citizens over a three-years period in seven areas of corporate social responsibility (namely: environment, community, corporate governance, diversity, employee relations, human rights, and product quality), showed that, when a company pursues CSR initiatives with the strongest priority and, overall, records better social outcome than other companies, the positive effect of its CSR initiatives on CP strengthens in terms of both market-based and accounting-based measures of performance. The main conclusion of that study is that best corporate citizens benefit better performance when they link their CSR initiatives to the likely preferences of their most salient stakeholders (prioritization approach to CSR) and undertake the corporate social actions that are relevant to the company's strategy (strategic approach to CSR). In other words, whether the firm's stakeholders have been identified and 
prioritized in their salience, the firm should link its CSR initiatives to the preferences of the most salient or the more relevant groups of stakeholders.

One limitation of the above study is in the fact that it relies only on best corporate performers and the extent to which the same relationship between CSR and CP holds for all companies across industries and time is ultimately an empirical question. The purpose of this study is to build on the work by Michelon et al. (2013) to provide further evidence about the CSR-CP link along the lines of those researchers (McWilliam and Siegel, 2001; Sen and Bhattacharya, 2004; Melo and GarridoMorgado, 2011) who have argued that only by channeling a firm's CSR initiatives to strategic objectives, directors and top executives can strength the firm's long-term competitiveness and $\mathrm{CP}$.

In our analysis, the evidence on the positive financial performance effects of prioritization and strategic approaches to CSR is much stronger than in the previous exploratory attempt (Michelon et al., 2013). Furthermore, we propose improved proxies for capturing prioritization and strategic approaches as well as additional tests showing insights on how the strategic approach to CSR-related issues is likely to be related to the nature of the business, such as membership to environmentally sensitive industries. The evidence further suggests that the positive effects in the CSR-CP relationship hold also after the financial crisis (especially for the strategic approach); and, finally, show that the variables of interest tend to deploy their stronger effects if used as complements and not substitutes, especially when managers deal with internal stakeholders such as shareholders (governance) and employees.

Indeed, managing the CSR initiatives of the firm in terms of doing things better than, and differently from competitors, can contribute to competitive success in the same way that other aspects of competitive strategy do (Porter and Kramer, 2006). By 
linking the CSR initiatives to the likely preferences of the stakeholders and channeling company CSR resources to objectives favored by top management and directors, companies can ensure that their corporate capabilities will be particularly suited to helping create value for the stakeholder groups whose salient needs they are trying to address (Ruf et al., 2001). The implications of our studies are discussed in the conclusions of the paper.

\section{Extension of the previous study}

Despite being one of the most highly researched areas in empirical managerial studies, the CSR-CP relationship in terms of companies' social actions toward specific stakeholder groups has always faced serious methodological issues. First, stakeholders' salience is mainly measured trough CEO survey (Mitchell et al., 1997) and thus it bears the risk of being highly subjective; second, corporate social responsibility is often outlined in long and qualitative sustainability reports (i.e. the Global Reporting Initiative guidelines) which need to be content analyzed; third, firmlevel decisions on CSR initiative are rarely taken at a governance level and often appear very disconnected and fragmented (Porter and Kramer, 2006); and, fourth, corporate social responsibility information are often hand-collected and screened by independent bodies (i.e. the KPMG CSR survey) in order to be treated for their positive or negative outcome with limited or no comparative analysis across corporations.

According to Porter and Kramer (2006), when companies approach CSR in this way, they "discover that CSR can be much more than a cost, a constraint, or a charitable deed - it can be a source of opportunity, innovation and competitive advantage". In other words, they claim that when managers and directors are able to prioritize their 
social agendas in order to achieve greater social impact, the effect of CSR on corporate financial performances will be positive.

To gain a better understanding of the nature of the CSR-CP relationship, Michelon et al. (2013) examined CSR initiatives in terms of corporate social performance (CSP) based on the likely preferences of different stakeholders groups. Michelon et al. looked at CSP scores of 188 corporations across three years and proposed two proxies: one for capturing the greater emphasis on some areas of CSR than other corporations (CSR prioritization) and one for capturing superior relative score in some areas of CSR than other corporations (strategic approach to CSR). Michelon et al. (2013) provide a new methodological approach to empirically test previous research assumptions such as: Welford, Chan and Man (2008) proposal about selected CSR actions as tools for improving companies' scanning skills, processes in a way that increases the organizational preparedness for change, turbulence, and crises; Searcy, McCartney and Karapetrovic (2008) case study about the role of key stakeholders involvement in identifying priorities for CSR actions; Alniacik, Alniacik, and Genc (2011) study on the role of positive but segmented CSR information as particularly enduring advantage that is difficult to be imitated by competitors; DitlevSimonsen and Midttun (2011) analysis of managers' preference to pursue prioritized CSR mainly for targeting value maximization; and Brammer, Hoejmose and Marchant (2012) tests about the fewer benefits perceived by the smallest and less strategic companies engaged with environmental issues.

Despite their limitations, the two proxies proposed by Michelon et al. (2013), measured together, allow to capture what is at the core of strategically prioritized CSR activities and the preliminary results provided support for the assertion that CSR initiatives focused on few CSR areas (prioritization) and able to outperform other 
corporations' CSP (strategic) are positively associated with CP. However, these relationships were not observed for all of the seven areas of CSR. Tests for interactions between strategically prioritized CSR and the CSR-CP relationship found no interaction effect between $\mathrm{CP}$ and environment-related or employee-related CSR initiatives. Moreover, the sample used was biased towards the best performers, as it included only companies belonging to the Top 100 Best Corporate Citizens. So the extent to which results would hold for other types of companies is not clear. Using variance and top tiers between companies' CSP as proxies for prioritization and strategic approaches to CSR (Michelon et al., 2013; Wang and Choi, 2010) forces researchers to enlarge datasets as much as possible in order to better investigate the reliability and robustness of the research variables. Because of the limited size and bias towards best performers of the sample used in Michelon et al. (2013), it remains undetermined whether their results would have held for a larger cross-section of companies operating in different industries with different structural characteristics and facing different competitive external challenges.

The following sections of this paper will further investigate the reliability of the proxies proposed by Michelon et al. (2013) in a larger sample, over 5 times more companies (from 188 to over 900); for a larger number of years (from 3 to 9 years); across different industries (environmentally sensitive industries vs. others); taking into consideration different competitive challenges (before and after the financial crisis of 2007); and introducing stronger lagged effects and control variables in modeling the relationship between CSP and CP. The ultimate goal is to propose to the academic community further evidence about the validity of investigating the variance and top tiers in CSR as valuable proxies of specific firm-level decision such as the 
relevance of prioritized corporate social actions and the possibility to build a competitive advantage based on selected corporate social actions.

\section{Research Method}

Sample selection

We base our analysis on a sample of US firms over the period 2003-2011. We retrieve CSR data from the KLD database while we compute corporate performance data from Compustat. Although we start from are more than 20,000 observations resulting from the merge of Compustat and KLD, we lose 2,861 firm-years' observations where there is missing data for computing the full set of corporate performance measures and the control variables. Furthermore, in order to ensure that our results are not driven by changes in the coverage of firms by KLD, we restrict our analysis to a balanced panel of firms that are covered each year of the period considered. We end up with 8,910 firm-year observations, for 990 unique firms over the period 2003-2011 which are simultaneously covered by both datasets along the nine years considered in the study.

\section{Measures of corporate performance $(C P)$}

Following Michelon et al. (2013), we measure company's performance in terms of short-term accounting-based measures, long-term accounting-based measures, and market-based measures. For accounting-based measures, we consider EBITDA, Capital Expenditure, and Intangibles. For the market-based measure, we select companies' market value at the end of each of fiscal year. We use both concurrent and leading performance data in our main analyses.

\section{Measurement of Corporate Social Performance (CSP)}

The independent variables used in this study are the seven areas of stakeholder management on which KLD rates company's CSR initiatives: environment, 
community, corporate governance, diversity, employee relations, human rights, and product quality and safety. As KLD ratings indicate the presence of strengths and weaknesses in each of the seven areas of CSR (Mattingly and Berman, 2006), a low rating is indicative of weakness or the absence of strength, while a high rating indicates the presence of positive activity toward a stakeholder group and the absence of weaknesses.

Measures of strategically prioritized CSR activities

While we follow Michelon et al. (2013) in their spirit of measuring strategically prioritized CSR activities, we do bring an important innovation, in that we calibrate our measures on the industry to which each company belongs. Indeed, a company that prioritizes its CSR initiatives to the likely preferences of the stakeholders (captured by greater emphasis on some areas of CSR than others) and then uses CSR resources strategically to pursue those CSR objectives (reflected by superior relative score in some areas of CSR than others), will most likely do so benchmarking itself with the industry peers. Thus, given that we have great variability across industries which was very limited in Michelon et al. (2013) setting of the 100 best corporate citizens, we consider prioritization of stakeholders as well as the strategic approach to CSR as driven by the type of industry in which the firm is operating.

We follow Michelon et al. (2013) and we measure the extent to which a company prioritizes its CSR initiatives by considering the variance in each company's CSR rating related to the seven areas in each of the 9 years. We create a dummy variable for "priority" equal to 1 if the variance of each firm is greater than the industry (defined following the two-digits SIC codes) average variance in each year 
and 0 otherwise. This measure aims at capturing whether CSR initiatives are selectively linked to its stakeholders' preferences.

Next, to measure whether a company adopts a strategic approach to CSR in each of the areas covered by the KLD dataset, we consider the mean score for each of the seven areas of CSR for all the companies within each industry (defined following the two-digits SIC codes) in each year. If a company's score is higher than the overall mean for a given year/industry for a specific area of CSR, we classify the company as addressing the demands of that stakeholder group in a strategic way. Accordingly, a dummy variable "strategic" is created, and companies are given a value equal to 1 if a company's score is higher than the overall industry-year mean and 0 otherwise. Seven dummy variables, one for each area of CSR, are created in this way.

Although these measure still suffer from limitation, we argue that they do capture the core of strategically prioritized CSR activities and are aligned with approaches previously used (Wang and Choi, 2010). Table 1 provides a summary of variables definitions.

Insert Table 1 about here

\section{Modeling the Effect of Strategically Prioritized CSR}

Following Michelon et al. (2013), we run the following models with year and industry fixed effects and panel-corrected standard errors assuming within-unit homoscedasticity:

$$
\begin{gathered}
\text { Company Performance }_{i t}=\beta_{0}+\beta_{1} \text { community }_{i t}+\beta_{2} \text { governance }_{i t}+ \\
\beta_{3} \text { diversity }_{i t}+\beta_{4} \text { employe }_{i t}+\beta_{5} \text { environment }_{i t}+\beta_{6} \text { humanrights }_{i t}+ \\
\beta_{7} \text { product }_{i t}+\beta_{8} \text { size }_{i t}
\end{gathered}
$$


We also take care of the simultaneity in the CSR-CP relationship by considering a lagged effect, in which strategically prioritized CSR measures at time $t$ are regressed on company performance during time $t+1$, as follows:

(2) Company Performance ${ }_{i(t+1)}=\beta_{0}+\beta_{1}$ community $_{i t}+\beta_{2}$ governance $_{i t}+$ $\beta_{3}$ diversity $_{i t}+\beta_{4}$ employe $_{i t}+\beta_{5}$ environment $_{i t}+\beta_{6}$ humanrights $_{i t}+$

$$
\beta_{7} \text { product }_{i t}+\beta_{8} \text { size }_{i t}
$$

We include size as control variables based on the recommendations and findings of previous researchers (McWilliams and Siegel, 2000; Coombs and Gilley, 2005; Choi and Wang, 2009). We measure firm size by the natural logarithm of the sales. Our models also take into consideration industry and year fixed effects.

Next, in order to examine the effect of strategically prioritized CSR activities on $\mathrm{CP}$, we use moderated multiple regressions, run with year and industry fixed effects and panel corrected standard errors. We specified the following models to test this relationship:

$$
\begin{gathered}
\text { Company Performance }_{i t}=\beta_{0}+\beta_{1} \text { priority }_{i t}+\beta_{2} \text { CSR }_{i t}+\beta_{3} \text { strategic }_{i t} \\
+\beta_{4} \text { CSR }_{i t} * \text { Strategic }_{i t}+\beta_{5} \text { size }_{i t}
\end{gathered}
$$

$$
\begin{gathered}
\text { Company Performance }_{i(t+1)}=\beta_{0}+\beta_{1} \text { priority }_{i t}+\beta_{2} \text { CSR }_{i t}+ \\
\beta_{3} \text { strategic }_{i t}+\beta_{4} \text { CSR }_{i t} * \text { Strategic }_{i t}+\beta_{5} \text { size }_{i t}
\end{gathered}
$$

Where $i, t$ indicate, respectively, firm and year observations; company performance is measured by EBITDA, market value, capital expenditure, and intangible assets; priority is a dummy variable that indicates whether the CSR initiatives of the company are linked to stakeholder preferences; CSR is the KLD ratings in the areas of community, governance, diversity, employees, environment, human rights, and 
product; Strategic is a dummy variable that indicates whether the company channeled its CSR resources to CSR initiatives in a strategic way in the seven areas of CSR; size is a logarithmic transformation of sales.

\section{Results}

Table 2 reports descriptive statistics and correlations for the variables included in the study. The characteristics associated with the companies included in the sample are reported in terms of the average EBITDA, market value, capital expenditures and intangible assets. Also included in Table 2 are the CSR performance ratings of companies in the sample. On average, companies perform better with issues involving diversity (mean=0.27), community relations (mean=0.08), and environment (mean $=0.04)$ than they do on issues related to human rights (mean=-0.06), product responsibility (mean=-0.20), employee relations (mean=-0.20) and governance (mean=-0.39). As expected, these average rankings are much lower than in Michelon et al. (2013), since their sample was restricted to the best performers. Nevertheless, similarly to their evidence, the standard deviation associated with each rating indicates a fair degree of variation among companies in their corporate social actions; ratings on diversity, employee relations and environmental issues show the largest variance, while human rights and community ratings have the lowest variance.

Insert Table 2 about here

Table 3 presents the results of the main effect models (equation 1 and 2), in which both concurrent and future $\mathrm{CP}$ (measured in terms of EBITDA, capital expenditure, company market value, and intangibles) is regressed on the seven areas of CSR while controlling for company size, industry and year fixed effects in order to determine the nature of the CSR-CP relationship. Results provide mixed evidence 
about the relationship between CSR and concurrent CP. While community and diversity-related CSR initiatives are positively and significantly associated with all of the four performance measures, we get the opposite evidence for human rights and the product-related CSR activities, which are significantly and negatively associated to the $\mathrm{CP}$ measures. Governance is significantly and positively associated with both EBITDA and capital expenditure (concurrent and future), environment is also associated with these two measures of $\mathrm{CP}$ but negatively. Finally employee related CSR activities are positive related only to two of our CP measures (EBITDA and market value). The CSR-CP relationship is stronger (as is evident in the variance explained) in terms of the financial performance measures-EBITDA ( $\mathrm{r}$ square $=0.475)$, market value $(\mathrm{r}$ square $=0.443)$ and capital expenditure $(\mathrm{r}$ square $=0.399)$ than in terms of the intangibles ( $\mathrm{r}$ square $=0.303)$.

We get consistent results if we consider the relationship between the various areas and future $C P$ : all coefficients are significant and have the same sign, except for community performance and future capital expenditure, for which the coefficient becomes insignificant. On the overall, this mixed evidence is consistent to the findings of Michelon et al. (2013), Chiu and Sharfman, (2009) and Orlitzky et al., 2003).

Insert Table 3 about here

Following Michelon et al. (2013), in order to investigate the effects of CSR initiatives that are prioritized via strategic concerns on the CSR-CP relationship, we run seven moderated multiple regressions, one for each of the specific areas of CSR initiatives (equation 3). The effect of each variable is analyzed after controlling for size, industry and year fixed effects. The model considers the main effect of each 
CSR areas as well as the interaction term examining the moderating effect of the strategic approach adopted in each of the seven areas of CSR across the four performance measures. Results are presented in Table 4.

Insert Table 4 about here

The coefficient for Priority, which measures the attempt of firms to link the firm's CSR initiatives to the likely preferences of the stakeholders, is positively associated with concurrent $\mathrm{CP}$ in each of the areas of CSR initiatives, except diversity. In terms of the various measures of $\mathrm{CP}$ that we use, prioritization appears to play a role in the CSR-CP relationships more in terms of EBITDA, market value and intangibles than in terms of capital expenditure. While the results obtained for EBITDA and market value are very well aligned with those of Michelon et al. (2013), they find an effect of prioritization in the relationship between CSR and capital expenditure, which is more rare in our setting. Nevertheless, the evidence still supports the assertion that CSR initiatives based on prioritization of stakeholders are positively associated with CP.

In terms of the moderating effect of a strategic approach in the various CSR areas on the CSR-CP relationship we find that twenty-five of the 28 potential interaction effects (seven area of CSR across four corporate performance measures) are significant and in the predicted direction (positive effect).

A strategic approach to CSR initiative positively moderates the CSR-CP relationship in terms of all the seven CSR areas, when corporate performance is measured in terms of EBITDA or capital expenditure. The moderating effect cannot be traced in one area (environment) when corporate performance is measured in terms of company's market value and in two areas (community and environment) when $\mathrm{CP}$ 
is measures as intangibles. The evidence on the moderating effects is much stronger than in Michelon et al. (2013) although they still require further explanation and discussion.

In seventeen cases, twelve of which were statistically significant, the CSR main effect is negative and the interaction effect is positive. For example, human rights and product-related CSR actions are - by themselves - negatively related to all of the CP measures considered, but the interaction terms are positive. Similarly, governance-related CSR is negatively related to company value, but the interaction term is significant and positive. While this evidence was also present in Michelon et al. (2013), the results obtained in this study provide stronger and further support to the fact that, while CSR initiatives in certain areas may have a negative effect on CP (presumably in terms of the cost incurred and the benefits derived), when the company's CSR resources are used in a strategic manner to pursue social objectives that are favored by the company's stakeholders, performance is likely to improve.

Results obtained considering future $\mathrm{CP}$ (equation 4) provide qualitatively the same evidence (Table 5), although the association between prioritization of stakeholders' needs and CP is less noticeable as seven coefficients (out of twenty) become insignificant. On the other side, the moderating effects of the strategic allocation of CSR resource hold very well and support the idea that stakeholders relationship have a persistent effect on company performance (Choi and Wang, 2009).

\section{Insert Table 5 about here}

\section{Additional tests}

We perform three additional tests aimed at providing further insights into the CSR-CP relationship. 
The first test aims at providing an insight into the so called environmentally sensitive industries, where exposure to public pressure for the safeguard of the environment is particularly high, because of the concerns of the general public, political bodies as well as regulatory agency (Cho and Patten, 2007). Following Cho and Patten (2007), we separated firms that operate primarily in environmentally sensitive industries (ESI) from those that do not (non-ESI). ESI firms are defined as companies with a two-digits SIC code equal to: 13 (oil exploration), 26 (paper), 28 (chemical and allied products), 29 (petroleum refining), 33 (metals), 10 (mining) or 49 (utilities). We expect that a strategically prioritized approach to the environment will have a greater effect for ESI than non-ESI firms. We thus run equation 3 separately for ESI and non-ESI firms. Results are reported in Table 6.

Insert Table 6 about here

The coefficient for Priority, which measures the attempt of firms to link the firm's CSR initiatives to the likely preferences of the stakeholders, is positively associated with EBITDA and market value for both ESI and non-ESI firms. Nevertheless, the coefficients of priority for ESI firms present a greater magnitude than for non-ESI. When performance is measured as EBITDA, the main effect (environment) is negative and significant for ESI firms, while it is still negative but not significant for non-ESI firms. When performance is measured as capital expenditure, we find a significant and negative coefficient for the main effect (environment) and a significant and positive coefficient for the moderating effect (environment*strategic) for both ESI and non-ESI firms, but for ESI firms the coefficients are much greater in absolute value. This evidence points towards the fact that the process of prioritization and strategic approach in relation to environmental- 
related CSR activities strengthen the CSR-CP relationship more in ESI than non-ESI firms.

In the second analysis, we look at whether the relationship between strategically prioritized CSR activities and $\mathrm{CP}$ was affected by the financial crisis that started in 2007 with the liquidity shortfall of the banking system. During the financial downturn, stock indexes fell, various financial institutions collapsed, unemployment grew. Under these circumstances, companies might either restrict their investment on CSR as it generates costs (Orlitzky et al. 2003) or else use CSR to foster further their CP. Therefore it is unclear whether our evidence is somewhat biased by the happening of the financial crisis that has raised concerns over the role of businesses in the society, the corporate governance models of firms, the welfare of thousands of employees as well as undermined customer trust in well respected brands. For this reasons, we run equation 3 separately in the pre-crisis period (2003-2006) and in the post-crisis period (2007-2011) for four of the seven CSR areas: community, governance, employee and product, which we believe were the most affected by the unfolding of the crisis. Table 7 presents the results of this analysis.

\section{Insert Table 7 about here}

While running the regression separately for the pre and post crisis period does not qualitatively lead us to falsify our previous results, we do still notice that the effect of prioritization on CP is generally attenuated in the post crisis period (eight of the sixteen coefficients are not significant, although positive). On the other side, the moderating effect of a strategic use of CSR resources seems to hold well also after the crisis: only three of the sixteen interaction coefficients are not significant. This analysis suggests that despite the negative forces played by the financial crisis over 
corporate performance, a strategically prioritized approach to CSR seems to strengthen the CSR-CP relationship.

In our third test we acknowledge that prioritization and a strategic approach to CSR are not independent strategies, and that they can either work as complements or substitutes. Therefore we run the model descripted by equation 3 separately for those companies that prioritize vs. those that do not, for three CSR areas: community, governance and employee, where prioritization was found to have a strong effect on CP. Table 8 presents the results. For companies that do not prioritize, the main effect of the CSR area is significant in seven cases out twelve, but despite its significant, it is always negative, suggesting that for companies that do not prioritize between stakeholders need, the CSR-CP relationship is not present, or worse negative. In all cases where the main effect is significant and negative, the moderating effect is also significant and positive, suggesting that a strategic use of CSR resources can counterbalance the negative effect of non-prioritizing among stakeholders' preferences. For companies that $d o$ prioritize, the evidence is not straightforward. In the case of community-related CSR activities, the main effect is positive and significant for EBITDA, market value and intangibles, but there is no support for a significant interaction effect. We interpret this evidence as a signal that a strategic approach to community related CSR activities is a substitute, or at least, not a complement to prioritization of stakeholders' preference in affecting the CSR-CP relationship. Nevertheless we find that the opposite is true when we consider governance and employee-related CSR activities. Here the moderating effect is positive and significant in six out of eight cases, suggesting that the strategic use of CSR resources is adopted together with prioritization of stakeholders' preference to affect the CSR-CP relationship. 


\section{Discussion \& Conclusion}

To gain a better understanding of the nature of the CSR-CP relationship, this study examined CSR initiatives in terms of strategic choices that companies make and pursue based on the assumption, well supported in literature, that stakeholders are not all equally important in a specific time-framework or industry and strategic settings. Accordingly, managers interested in optimizing their CSR initiatives, in term of overall contribution of CSR to $\mathrm{CP}$, are called to design their CSR initiative according to the most relevant and salient stakeholder preferences.

In our results the evidence on the positive effects of prioritization and strategic approaches to CSR is much stronger than in the previous exploratory attempt (Michelon et al., 2013). This result was not obvious, considering the sensible increase in the number of companies tested and in the number of years observed, as well as the extension beyond best CSR performers.

Furthermore, the improved proxies tested in this research note for capturing prioritization and strategic approaches as well as our additional tests show insights on how the strategic approach to CSR-related issues are likely to be related to the nature of the business, such as membership to environmentally sensitive industries. Moreover we provide evidence of positive effects in the CSR-CP relationship also after the financial crisis (especially for the strategic approach); and, finally, we show that our variables of interest tend to deploy their stronger effects if used as complements and not substitutes, especially when managers deal with internal stakeholders such as shareholder (governance) and employees. In this last scenario, companies report better financial performance if, having focused on initiative related 
to those internal stakeholders, deploy CSR resources targeting better CSP then competitors.

It seems proved under several different circumstances, thus, that social benefits often reinforce and overlap with the corporate competitive advantage. No matter what type of the seven CSP one analyzes, data show there is always at least one company whose business model is able to capitalize on the link between better social performances and strengthened financials.

Given these results, we believe the proposed proxies represent a parsimonious way to observe the outcome of important strategic decisions managers are called to make about how to approach CSR in a timely and effective manner. The results indicate that companies whose CSR activities are prioritized have superior financial performance and that the process of prioritization together with the strategic approach adopted by the firm strengthens the CSR-CP relationship.

The fact that the coefficients of the seven CSP areas themselves were often negatively when associated to $\mathrm{CP}$, while the interaction effect with the strategic proxy was positive, suggests that, in the absence of strategic approaches, participating in social issues in general and not strategic terms leads to diminished financial outcomes. Accordingly, when implementing CSR initiatives, managers will see the largest impact (in term of both CSP and CP) if they channel their CSR resources in terms of strategic objectives related to the most salient stakeholder needs.

The evidence provided in this study has important implications for both managers and regulators. For managers, the findings suggest that, even though social investments made in any stakeholder domain may temporally pay in form of improved visibility, only prioritized and strategic oriented social investments are likely to impact on financial performance. On the opposite side, companies that 
ignore CSR initiatives aimed toward those stakeholder groups which are progressively becoming more relevant for the success of their business model may be penalized in the form of poor performance. Any social investment and initiative should thus be the outcome of accurate strategic planning in order to move from venture philanthropy to the generation of shared value between key stakeholders and shareholders. For regulators, this research stresses the difficulties in proposing broad and comprehensive multi-stakeholder disclosure policies. Successful companies leverage on the flexibility of their decision-making and target a stakeholder management, which varies over time, industries and companies' size. Any social or sustainability guideline should thus empathize an up-front screening of the most relevant stakeholder relationships and encourage managers to highlight and share with external audiences which aspects of their business model, in any specific given time, can be source of both: social value for all stakeholders and financial value for markets, tax authorities, employees, suppliers and other primary stakeholders. Social guidelines will better fit companies and communities needs if and when they require broad stakeholder reporting together with selected CSR investments plans and prioritized CSR agendas.

While this study reinforced the hypothesis that a strategic path to CSR is visible in the most known and studied CSP data (the KLD dataset, investigated in its largest version), the topic warrants additional investigation. First, future research could further disentangle what the proxies of prioritization and strategic approaches capture. Second, specific studies should move beyond correlating broad measures of a company's CSR initiatives with $\mathrm{CP}$ by examining direct measures of firm-level corporate social actions in order to better clarify the CSR decision-making process able to benefit both society and business. 


\section{References}

Alniacik U, Alniacik E, Genc N. 2011. How corporate social responsibility information influences stakeholders' intentions. Corporate Social Responsibility and Environmental Management. 18: 234-245. DOI: 10.1002/csr.245

Brammer S, Hoejmose S, Marchant K. 2012. Environmental management in the SMEs in the UK: practices, pressures and perceived benefits. Business Strategy and the Environment 21: 423-434. DOI: 10.1002/bse.717

Chiu S, Sharfman M. 2009. Legitimacy, visibility, and the antecedents of corporate social performance: An investigation of the instrumental perspective. Journal of Management. DOI: 10.1177/0149206309347958.

Cho $\mathrm{CH}$, Patten DM. 2007. The role of environmental disclosures as tools of legitimacy: a research note. Accounting, Organizations and Society 32: 639647. DOI: 10.1016/j.aos.2006.09.009

Choi J, Wang H. 2009. Stakeholder relations and the persistence of corporate financial performance. Strategic Management Journal 30: 895-907. DOI:10.1002/smj.759

Coombs JE, Gilley KM. 2005. Stakeholder management as a predictor of CEO compensation: Main effects and interactions with financial performance. Strategic Management Journal 26: 827-840. DOI:10.1002/smj.476

Ditlev-Simonsen CD, Midttun D. 2011. What motivates managers to pursue corporate responsibility? A survey among key stakeholders. Corporate Social Responsibility and Environmental Management 18: 25-38. DOI: $10.1002 /$ csr.237 
Mattingly JE, Berman SL. 2006. Measurement of corporate social action: Discovering taxonomy in the Kinder Lydenburg Domini Ratings Data. Business and Society 45: 20-46. DOI:10.1177/0007650305281939

McWilliams A, Siegel DS. 2001. Corporate social responsibility: A theory of the firm perspective. Academy of Management Review 26: 117-127. DOI:10.5465/AMR.2001.4011987

Melo T, Garrido-Morgado A. 2011. Corporate Reputation: A Combination of Social Responsibility and Industry. Corporate Social Responsibility and Environmental Management. DOI:10.1002/csr.260

Michelon G, Boesso G, Kumar K. 2013. Examining the link between strategic corporate social responsibility and company performance: an analysis of the best corporate citizens. Corporate Social Responsibility and Environmental Management 20: 81-94. DOI: $10.1002 /$ csr.1278

Mitchell RK, Agle BR, Wood DJ, 1997, Toward a theory of stakeholder identification and salience: defining the principle of who and what really counts. Academy of Management Review 22: 853-886.

Orlitzky M, Schmidt FL, Rynes SL. 2003. Corporate social and financial performance: A meta analysis. Organizational Studies 24: 403-441. DOI:10.1177/0170840603024003910

Porter ME, Kramer MR. 2006. Strategy and society: The link between competitive advantage and corporate social responsibility, Harvard Business Review 86: 7892.

Ruf B, Muralidhar K, Brown RM, Janney JJ, Paul K.. 2001. An empirical investigation of the relationship between change in corporate social 
performance and financial performance a stakeholder theory perspective. Journal of Business Ethics 32: 143-156. DOI: 10.1023/A:1010786912118

Searcy C, McCartney D, Karapetrovic S. 2008. Identifying priorities for action in corporate sustainable development indicator programs. Business Strategy and the Environment 17: 137-148. DOI: 10.1002/bse.509

Sen S, Bhattacharya CB. 2004. Doing better at doing good: When, why and how consumers respond to corporate social initiatives, California Management Review 47: 9-24. DOI:10.1509/jmkr.38.2.225.18838

Wang H, Choi J. 2010. A New Look at the Corporate Social-Financial Performance Relationship: The Moderating Roles of Temporal and Interdomain Consistency in Corporate Social Performance. Journal of Management. DOI: $10.1177 / 0149206310375850$

Welford R, Chan C, Man M. 2007. Priorities for corporate social responsibility. Corporate Social Responsibility and Environmental Management 15: 5-62. DOI: $10.1002 /$ csr.166 
Table 1. Variables definitions

\begin{tabular}{ll}
\hline Name & Measure \\
\hline EBITDA & Earnings before interest, tax, depreciation and amortization \\
MKT VALUE & Market Value of the company \\
CAP EXP & Capital Expenditure \\
INTANG & Intangible Assets \\
Community & KLD net score for Community \\
Governance & KLD net score for Governance \\
Diversity & KLD net score for Diversity \\
Employee & KLD net score for Employee \\
Environment & KLD net score for Environment \\
Human Rights & KLD net score for Human Rights \\
Product & KLD net score for Product \\
& Dummy variable equal to 1 if a company's score in a given KLD \\
Strategic CSR & (CSR) are is higher than the overall industry-year mean and 0 \\
& otherwise. Seven dummy variables, one for each area of CSR, are \\
created in this way. \\
Priority & $\begin{array}{l}\text { Dummy variable equal to 1 if the variance of each firm is greater than } \\
\text { the industry (defined following the two-digits SIC codes) average }\end{array}$ \\
Size & variance in each year and 0 otherwise. \\
\hline
\end{tabular}


Table 2. Descriptive statistics and correlation analysis

\begin{tabular}{|c|c|c|c|c|c|c|c|c|c|c|c|c|c|c|}
\hline & Mean & Std dev & 1 & 2 & 3 & 4 & 5 & 6 & 7 & 8 & 9 & 10 & 11 & 12 \\
\hline 1.EBITDA & $1,007.57$ & $3,167.46$ & 1 & & & & & & & & & & & \\
\hline $\begin{array}{l}\text { 2. MKT } \\
\text { VALUE }\end{array}$ & $7,764.41$ & $22,961.16$ & $0.874 * * *$ & 1 & & & & & & & & & & \\
\hline 3. CAP EXP & 365.56 & $1,256.91$ & $0.827^{* * *}$ & $0.626^{* * *}$ & 1 & & & & & & & & & \\
\hline 4. INTANG & $1,477.16$ & $5,925.18$ & $0.731 * * *$ & $0.659 * * *$ & $0.505^{* * *}$ & 1 & & & & & & & & \\
\hline 5. Community & 0.08 & 0.56 & $0.216^{* * *}$ & $0.254 * * *$ & $0.095^{* * *}$ & $0.217^{* * *}$ & 1 & & & & & & & \\
\hline 6. Governance & -0.39 & 0.76 & $-0.058 * * *$ & $-0.073 * * *$ & $-0.062 * * *$ & $-0.056^{* * *}$ & $0.088 * * *$ & 1 & & & & & & \\
\hline 7. Diversity & 0.27 & 1.48 & $0.413 * * *$ & $0.433 * * *$ & $0.285^{* * *}$ & $0.352 * * *$ & $0.318 * * *$ & 0.012 & 1 & & & & & \\
\hline 8. Employee & -0.20 & 0.93 & $0.071 * * *$ & $0.124 * * *$ & 0.001 & $0.030 * *$ & $0.125^{* * *}$ & $0.025^{*}$ & $0.115^{* * *}$ & 1 & & & & \\
\hline $\begin{array}{l}\text { 9. Environment } \\
\text { 10. Human }\end{array}$ & 0.04 & 0.94 & 0.004 & $0.064 * * *$ & $-0.103 * * *$ & $0.090 * * *$ & $0.353 * * *$ & $0.124 * * *$ & $0.182 * * *$ & $0.098 * * *$ & 1 & & & \\
\hline Rights & -0.06 & 0.29 & $-0.323 * * *$ & $-0.299 * * *$ & $-0.297 * * *$ & $-0.164 * * *$ & 0.006 & $0.082 * * *$ & $-0.130 * * *$ & $0.051 * * *$ & $0.133 * * *$ & 1 & & \\
\hline 11.Product & -0.20 & 0.65 & $-0.289 * * *$ & $-0.299 * * *$ & $-0.222 * * *$ & $-0.236 * * *$ & -0.017 & $0.104^{* * *}$ & $-0.181 * * *$ & $0.083 * * *$ & $0.117 * * *$ & $0.158^{* * *}$ & 1 & \\
\hline 12. Priority & 0.31 & 0.46 & $0.159^{* * *}$ & $0.177 * * *$ & $0.120 * * *$ & $0.126^{* * *}$ & $0.116^{* * *}$ & $-0.144 * * *$ & $0.122 * * *$ & $-0.070 * * *$ & $0.067 * * *$ & $-0.103 * * *$ & $-0.156^{* * *}$ & 1 \\
\hline 13. Size & 7.42 & 1.61 & $0.512 * * *$ & $0.493 * * *$ & $0.434 * * *$ & $0.382 * * *$ & $0.187 * * *$ & $-0.199 * * *$ & $0.433 * * *$ & $-0.025^{*}$ & $0.031 * *$ & $-0.227 * * *$ & $-0.322 * * *$ & $0.222 * * *$ \\
\hline
\end{tabular}

$* \mathrm{p}<.10,{ }^{* *} \mathrm{p}<.05,{ }^{* * *} \mathrm{p}<.01$ 
Table 3. CSR initiatives and CP

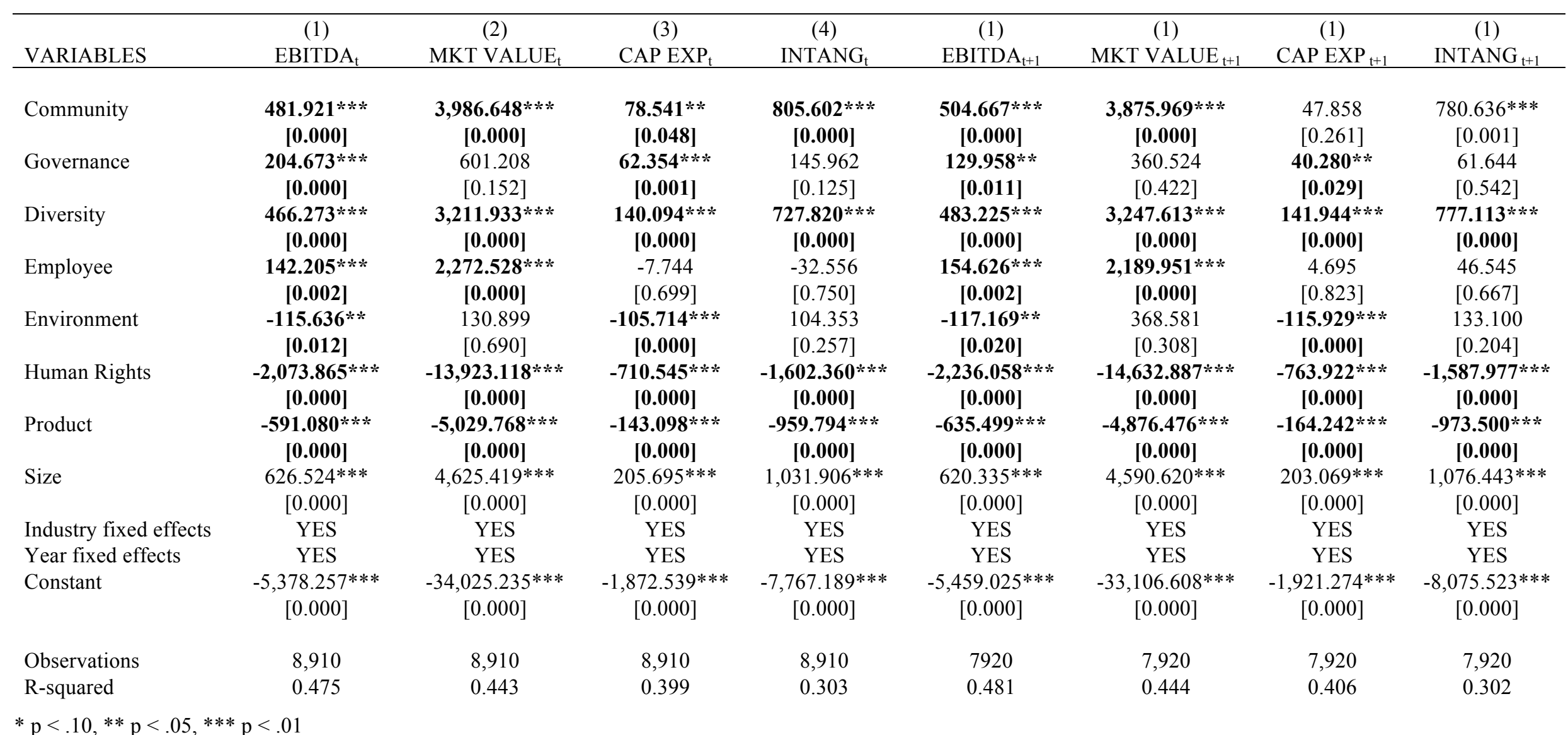


Table 4. Strategically prioritized CSR initiatives and CP

\begin{tabular}{|c|c|c|c|c|}
\hline & $\begin{array}{c}(1) \\
\text { EBITDA }_{t} \\
\end{array}$ & $\begin{array}{c}(2) \\
\text { MKT VALUE }_{t}\end{array}$ & $\begin{array}{c}(3) \\
\text { CAP EXP }_{t}\end{array}$ & $\begin{array}{c}(4) \\
\text { INTANG }_{t} \\
\end{array}$ \\
\hline Priority & $\begin{array}{c}127.353 * * \\
{[0.032]}\end{array}$ & $\begin{array}{c}2,036.177 * * * \\
{[0.000]}\end{array}$ & $\begin{array}{c}4.967 \\
{[0.851]}\end{array}$ & $\begin{array}{c}259.907 * * \\
{[0.034]}\end{array}$ \\
\hline Community & $\begin{array}{c}-144.331 \\
{[0.432]}\end{array}$ & $\begin{array}{c}1,135.785 \\
{[0.263]}\end{array}$ & $\begin{array}{c}-307.513 * * * \\
{[0.001]}\end{array}$ & $\begin{array}{c}815.981 * * * \\
{[0.001]}\end{array}$ \\
\hline Strategic & $\begin{array}{l}-20.174 \\
{[0.861]}\end{array}$ & $\begin{array}{l}552.370 \\
{[0.486]}\end{array}$ & $\begin{array}{c}-131.473 * * * \\
{[0.004]}\end{array}$ & $\begin{array}{l}44.747 \\
{[0.856]}\end{array}$ \\
\hline Community*Strategic & $\begin{array}{c}1,194.443 * * * \\
{[0.000]} \\
\end{array}$ & $\begin{array}{c}6,375.813 * * * \\
{[0.000]} \\
\end{array}$ & $\begin{array}{c}652.280 * * * \\
{[0.000]}\end{array}$ & $\begin{array}{l}565.547 \\
{[0.156]} \\
\end{array}$ \\
\hline Priority & $\begin{array}{c}251.236 * * * \\
{[0.000]}\end{array}$ & $\begin{array}{c}2,747.206 * * * \\
{[0.000]}\end{array}$ & $\begin{array}{l}\text { 50.201* } \\
{[0.054]}\end{array}$ & $\begin{array}{c}409.973 * * * \\
{[0.002]}\end{array}$ \\
\hline Governance & $\begin{array}{c}-213.902 \\
{[0.171]}\end{array}$ & $\begin{array}{c}-1,965.588 * \\
{[0.088]}\end{array}$ & $\begin{array}{l}-68.547 \\
{[0.268]}\end{array}$ & $\begin{array}{c}-147.333 \\
{[0.546]}\end{array}$ \\
\hline Strategic & $\begin{array}{c}420.515 * * * \\
{[0.007]}\end{array}$ & $\begin{array}{c}2,758.014 * * \\
{[0.014]}\end{array}$ & $\begin{array}{l}91.759 \\
{[0.149]}\end{array}$ & $\begin{array}{c}518.408 * * \\
{[0.033]}\end{array}$ \\
\hline Governance*Strategic & $\begin{array}{c}863.155 * * * \\
{[0.000]}\end{array}$ & $\begin{array}{c}6,295.607 * * * \\
{[0.000]} \\
\end{array}$ & $\begin{array}{c}247.019 * * * \\
{[0.000]}\end{array}$ & $\begin{array}{c}713.675 * * \\
{[0.015]} \\
\end{array}$ \\
\hline Priority & $\begin{array}{l}-71.114 \\
{[0.277]}\end{array}$ & $\begin{array}{c}404.826 \\
{[0.348]}\end{array}$ & $\begin{array}{l}-29.517 \\
{[0.340]}\end{array}$ & $\begin{array}{c}-207.182 \\
{[0.110]}\end{array}$ \\
\hline Diversity & $\begin{array}{c}134.537 * * \\
{[0.011]}\end{array}$ & $\begin{array}{c}366.624 \\
{[0.318]}\end{array}$ & $\begin{array}{l}30.739 \\
{[0.183]}\end{array}$ & $\begin{array}{l}172.561 \\
{[0.104]}\end{array}$ \\
\hline Strategic & $\begin{array}{c}-774.007 * * * \\
{[0.000]}\end{array}$ & $\begin{array}{c}-4,679.340 * * * \\
{[0.000]}\end{array}$ & $\begin{array}{c}-204.288 * * * \\
{[0.000]}\end{array}$ & $\begin{array}{c}-1,484.532 * * * \\
{[0.000]}\end{array}$ \\
\hline Diversity*Strategic & $\begin{array}{c}839.567 * * * \\
{[0.000]}\end{array}$ & $\begin{array}{c}6,775.525 * * * \\
{[0.000]} \\
\end{array}$ & $\begin{array}{c}219.580 * * * \\
{[0.000]}\end{array}$ & $\begin{array}{c}1,477.020 * * * \\
{[0.000]}\end{array}$ \\
\hline Priority & $\begin{array}{c}229.881 * * * \\
{[0.000]}\end{array}$ & $\begin{array}{c}2,613.178 * * * \\
{[0.000]}\end{array}$ & $\begin{array}{l}42.240 \\
{[0.136]}\end{array}$ & $\begin{array}{c}280.649 * * \\
{[0.046]}\end{array}$ \\
\hline Employee & $\begin{array}{l}-34.176 \\
{[0.749]}\end{array}$ & $\begin{array}{c}1,099.328 * \\
{[0.076]}\end{array}$ & $\begin{array}{c}-88.043^{*} \\
{[0.093]}\end{array}$ & $\begin{array}{c}-511.632 * * \\
{[0.033]}\end{array}$ \\
\hline Strategic & $\begin{array}{c}207.497 * * \\
{[0.049]}\end{array}$ & $\begin{array}{c}461.314 \\
{[0.475]}\end{array}$ & $\begin{array}{c}103.618 * * \\
{[0.037]}\end{array}$ & $\begin{array}{c}666.735 * * * \\
{[0.003]}\end{array}$ \\
\hline Employee*Strategic & $\begin{array}{c}433.253 * * * \\
{[0.001]}\end{array}$ & $\begin{array}{c}4,013.088 * * * \\
{[0.000]}\end{array}$ & $\begin{array}{c}128.903 * * \\
{[0.028]}\end{array}$ & $\begin{array}{c}949.806 * * * \\
{[0.001]}\end{array}$ \\
\hline Priority & $\begin{array}{c}235.165 * * * \\
{[0.000]}\end{array}$ & $\begin{array}{c}2,741.318 * * * \\
{[0.000]}\end{array}$ & $\begin{array}{c}58.618 * * \\
{[0.023]}\end{array}$ & $\begin{array}{c}349.250 * * * \\
{[0.005]}\end{array}$ \\
\hline Environment & $\begin{array}{c}-137.393 \\
{[0.111]}\end{array}$ & $\begin{array}{c}1,175.637^{* *} \\
{[0.021]}\end{array}$ & $\begin{array}{c}-178.321 * * * \\
{[0.000]}\end{array}$ & $\begin{array}{c}656.040 * * * \\
{[0.000]}\end{array}$ \\
\hline Strategic & $\begin{array}{c}-150.756 * \\
{[0.064]}\end{array}$ & $\begin{array}{c}-750.666 \\
{[0.232]}\end{array}$ & $\begin{array}{c}-0.607 \\
{[0.985]}\end{array}$ & $\begin{array}{c}-483.699 * * * \\
{[0.007]}\end{array}$ \\
\hline Environment*Strategic & $\begin{array}{c}422.619 * * * \\
{[0.000]}\end{array}$ & $\begin{array}{l}769.540 \\
{[0.281]}\end{array}$ & $\begin{array}{c}184.069 * * * \\
{[0.000]}\end{array}$ & $\begin{array}{c}-174.013 \\
{[0.374]}\end{array}$ \\
\hline
\end{tabular}

$* \mathrm{p}<.10, * * \mathrm{p}<.05, * * * \mathrm{p}<.01$ 
Table 4 (continued). Strategically prioritized CSR initiatives and CP

\begin{tabular}{|c|c|c|c|c|}
\hline & $\begin{array}{c}(1) \\
\text { EBITDA }_{t}\end{array}$ & $\begin{array}{c}(2) \\
\text { MKT VALUE }\end{array}$ & $\begin{array}{c}(3) \\
\text { CAP EXP }\end{array}$ & $\begin{array}{c}(4) \\
\text { INTANG }_{\mathrm{t}}\end{array}$ \\
\hline Priority & $\begin{array}{c}149.770 * * \\
{[0.016]}\end{array}$ & $\begin{array}{c}2,177.492 * * * \\
{[0.000]}\end{array}$ & $\begin{array}{l}20.520 \\
{[0.437]}\end{array}$ & $\begin{array}{c}286.187 * * \\
{[0.025]}\end{array}$ \\
\hline Human Rights & $\begin{array}{c}-2,679.911^{* * * *} \\
{[0.000]}\end{array}$ & $\begin{array}{c}-16,976.530 * * * \\
{[0.000]}\end{array}$ & $\begin{array}{c}-954.970 * * * \\
{[0.000]}\end{array}$ & $\begin{array}{c}-2,168.280 * * * \\
{[0.000]}\end{array}$ \\
\hline Strategic & $\begin{array}{l}104.908 \\
{[0.388]}\end{array}$ & $\begin{array}{c}-179.145 \\
{[0.819]}\end{array}$ & $\begin{array}{l}79.128 \\
{[0.144]}\end{array}$ & $\begin{array}{l}-92.619 \\
{[0.606]}\end{array}$ \\
\hline HumanR*Strategic & $\begin{array}{c}4,171.208 * * * \\
{[0.000]}\end{array}$ & $\begin{array}{c}27,348.807 * * * \\
{[0.000]}\end{array}$ & $\begin{array}{c}1,227.556 * * * \\
{[0.000]}\end{array}$ & $\begin{array}{c}4,974.205 * * * \\
{[0.006]}\end{array}$ \\
\hline Priority & $\begin{array}{c}136.241 * * \\
{[0.031]}\end{array}$ & $\begin{array}{c}2,015.935 * * * \\
{[0.000]}\end{array}$ & $\begin{array}{l}23.541 \\
{[0.375]}\end{array}$ & $\begin{array}{c}254.638^{*} \\
{[0.075]}\end{array}$ \\
\hline Product & $\begin{array}{c}-1,065.994 * * * \\
{[0.000]}\end{array}$ & $\begin{array}{c}-8,652.450 * * * \\
{[0.000]}\end{array}$ & $\begin{array}{c}-296.662 * * * \\
{[0.000]}\end{array}$ & $\begin{array}{c}-1,244.585 * * * \\
{[0.000]}\end{array}$ \\
\hline Strategic & $\begin{array}{c}369.364 * * * \\
{[0.001]}\end{array}$ & $\begin{array}{c}3,891.154 * * * \\
{[0.000]}\end{array}$ & $\begin{array}{c}103.217 * * \\
{[0.010]}\end{array}$ & $\begin{array}{l}326.192 \\
{[0.153]}\end{array}$ \\
\hline Product*Strategic & $\begin{array}{c}1,230.345 * * * \\
{[0.000]}\end{array}$ & $\begin{array}{c}9,008.102 * * * \\
{[0.000]}\end{array}$ & $\begin{array}{c}305.705 * * * \\
{[0.000]}\end{array}$ & $\begin{array}{c}720.025^{*} \\
{[0.068]}\end{array}$ \\
\hline
\end{tabular}

$* \mathrm{p}<.10,{ }^{* *} \mathrm{p}<.05, * * * \mathrm{p}<.01$ 
Table 5. Strategically prioritized CSR initiatives and future CP

\begin{tabular}{|c|c|c|c|c|}
\hline & $\begin{array}{c}(5) \\
\text { EBITDA }_{t+1} \\
\end{array}$ & $\begin{array}{c}(6) \\
\text { MKT VALUE }_{t+1}\end{array}$ & $\begin{array}{c}(7) \\
\text { CAP EXP }_{t+1} \\
\end{array}$ & $\begin{array}{c}(8) \\
\text { INTANG }_{t+1}\end{array}$ \\
\hline Priority & $\begin{array}{l}98.747 \\
{[0.133]}\end{array}$ & $\begin{array}{c}1,651.370 * * * \\
{[0.000]}\end{array}$ & $\begin{array}{c}-4.123 \\
{[0.889]}\end{array}$ & $\begin{array}{l}183.415 \\
{[0.182]}\end{array}$ \\
\hline Community & $\begin{array}{c}-278.049 \\
{[0.158]}\end{array}$ & $\begin{array}{l}493.822 \\
{[0.648]}\end{array}$ & $\begin{array}{c}-413.444 * * * \\
{[0.000]}\end{array}$ & $\begin{array}{c}759.320 * * * \\
{[0.004]}\end{array}$ \\
\hline Strategic & $\begin{array}{l}-34.111 \\
{[0.781]}\end{array}$ & $\begin{array}{c}967.972 \\
{[0.247]}\end{array}$ & $\begin{array}{c}-117.971 * * \\
{[0.017]}\end{array}$ & $\begin{array}{l}154.779 \\
{[0.550]}\end{array}$ \\
\hline Community*Strategic & $\begin{array}{c}1,471.602 * * * \\
{[0.000]}\end{array}$ & $\begin{array}{c}7,253.845 * * * \\
{[0.000]} \\
\end{array}$ & $\begin{array}{c}772.619 * * * \\
{[0.000]}\end{array}$ & $\begin{array}{l}615.575 \\
{[0.159]} \\
\end{array}$ \\
\hline Priority & $\begin{array}{c}220.200 * * * \\
{[0.002]}\end{array}$ & $\begin{array}{c}2,231.931 * * * \\
{[0.000]}\end{array}$ & $\begin{array}{l}43.542 \\
{[0.137]}\end{array}$ & $\begin{array}{c}\text { 299.404* } \\
{[0.051]}\end{array}$ \\
\hline Governance & $\begin{array}{c}-293.713 * \\
{[0.087]}\end{array}$ & $\begin{array}{c}-2,652.355 * * \\
{[0.031]}\end{array}$ & $\begin{array}{l}-74.815 \\
{[0.270]}\end{array}$ & $\begin{array}{c}-258.318 \\
{[0.343]}\end{array}$ \\
\hline Strategic & $\begin{array}{c}375.199 * * \\
{[0.029]}\end{array}$ & $\begin{array}{c}2,786.130 * * \\
{[0.020]}\end{array}$ & $\begin{array}{l}67.207 \\
{[0.337]}\end{array}$ & $\begin{array}{c}\text { 443.006* } \\
{[0.099]}\end{array}$ \\
\hline Governance*Strategic & $\begin{array}{c}961.616 * * * \\
{[0.000]}\end{array}$ & $\begin{array}{c}7,377.647 * * * \\
{[0.000]}\end{array}$ & $\begin{array}{c}259.612 * * * \\
{[0.000]}\end{array}$ & $\begin{array}{c}750.177 * * \\
{[0.019]}\end{array}$ \\
\hline Priority & $\begin{array}{l}-73.887 \\
{[0.299]}\end{array}$ & $\begin{array}{l}155.805 \\
{[0.732]}\end{array}$ & $\begin{array}{l}-25.853 \\
{[0.442]}\end{array}$ & $\begin{array}{c}-296.792 * * \\
{[0.037]}\end{array}$ \\
\hline Diversity & $\begin{array}{c}126.642 * * \\
{[0.026]}\end{array}$ & $\begin{array}{c}380.164 \\
{[0.327]}\end{array}$ & $\begin{array}{l}37.080 \\
{[0.138]}\end{array}$ & $\begin{array}{l}93.709 \\
{[0.411]}\end{array}$ \\
\hline Strategic & $\begin{array}{c}-864.498 * * * \\
{[0.000]}\end{array}$ & $\begin{array}{c}-5,504.607 * * * \\
{[0.000]}\end{array}$ & $\begin{array}{c}-231.051 * * * \\
{[0.000]}\end{array}$ & $\begin{array}{c}-1,652.258 * * * \\
{[0.000]}\end{array}$ \\
\hline Diversity*Strategic & $\begin{array}{c}909.956 * * * \\
{[0.000]}\end{array}$ & $\begin{array}{c}7,085.289 * * * \\
{[0.000]}\end{array}$ & $\begin{array}{c}222.596 * * * * \\
{[0.000]}\end{array}$ & $\begin{array}{c}1,706.506 * * * \\
{[0.000]}\end{array}$ \\
\hline Priority & $\begin{array}{c}222.604 * * * \\
{[0.002]}\end{array}$ & $\begin{array}{c}2,287.965 * * * \\
{[0.000]}\end{array}$ & $\begin{array}{l}38.804 \\
{[0.224]}\end{array}$ & $\begin{array}{l}177.399 \\
{[0.267]}\end{array}$ \\
\hline Employee & $\begin{array}{l}-50.369 \\
{[0.679]}\end{array}$ & $\begin{array}{c}1,028.643 \\
{[0.139]}\end{array}$ & $\begin{array}{l}-87.739 \\
{[0.146]}\end{array}$ & $\begin{array}{c}-530.055^{* *} \\
{[0.049]}\end{array}$ \\
\hline Strategic & $\begin{array}{c}264.285 * * \\
{[0.037]}\end{array}$ & $\begin{array}{l}540.313 \\
{[0.474]}\end{array}$ & $\begin{array}{c}\text { 116.408* } \\
{[0.057]}\end{array}$ & $\begin{array}{c}744.229 * * * \\
{[0.006]}\end{array}$ \\
\hline Employee*Strategic & $\begin{array}{c}456.889 * * * \\
{[0.003]}\end{array}$ & $\begin{array}{c}3,986.484 * * * \\
{[0.000]}\end{array}$ & $\begin{array}{c}141.808^{* * *} \\
{[0.040]}\end{array}$ & $\begin{array}{c}1,119.760 * * * \\
{[0.001]}\end{array}$ \\
\hline Priority & $\begin{array}{c}221.599 * * * \\
{[0.001]}\end{array}$ & $\begin{array}{c}2,326.597 * * * \\
{[0.000]}\end{array}$ & $\begin{array}{l}54.993^{*} \\
{[0.056]}\end{array}$ & $\begin{array}{c}269.614^{*} \\
{[0.054]}\end{array}$ \\
\hline Environment & $\begin{array}{c}-160.141 * \\
{[0.084]}\end{array}$ & $\begin{array}{c}981.077 * \\
{[0.072]}\end{array}$ & $\begin{array}{c}-209.409 * * * \\
{[0.000]}\end{array}$ & $\begin{array}{c}784.832 * * * \\
{[0.000]}\end{array}$ \\
\hline Strategic & $\begin{array}{c}-128.686 \\
{[0.166]}\end{array}$ & $\begin{array}{c}-461.030 \\
{[0.505]}\end{array}$ & $\begin{array}{c}4.974 \\
{[0.892]}\end{array}$ & $\begin{array}{c}-610.159 * * * \\
{[0.002]}\end{array}$ \\
\hline Environment*Strategic & $\begin{array}{c}438.890 * * * \\
{[0.000]}\end{array}$ & $\begin{array}{c}1,163.180 \\
{[0.138]}\end{array}$ & $\begin{array}{c}209.979 * * * \\
{[0.000]}\end{array}$ & $\begin{array}{c}-318.807 \\
{[0.157]}\end{array}$ \\
\hline
\end{tabular}

$* \mathrm{p}<.10, * * \mathrm{p}<.05, * * * \mathrm{p}<.01$ 
Table 5 (continued). Strategically prioritized CSR initiatives and future CP

\begin{tabular}{|c|c|c|c|c|}
\hline & $\begin{array}{c}(5) \\
\text { EBITDA }_{t+1}\end{array}$ & $\begin{array}{c}(6) \\
\text { MKT VALUE }_{t+1}\end{array}$ & $\begin{array}{c}(7) \\
\text { CAP EXP }_{t+1}\end{array}$ & $\begin{array}{c}(8) \\
\text { INTANG }_{t+1}\end{array}$ \\
\hline Priority & $\begin{array}{c}127.415^{*} \\
{[0.063]}\end{array}$ & $\begin{array}{c}1,729.479 * * * \\
{[0.000]}\end{array}$ & $\begin{array}{c}14.693 \\
{[0.616]}\end{array}$ & $\begin{array}{l}203.323 \\
{[0.157]}\end{array}$ \\
\hline Human Rights & $\begin{array}{c}-2,823.959 * * * \\
{[0.000]}\end{array}$ & $\begin{array}{c}-17,340.326 * * * \\
{[0.000]}\end{array}$ & $\begin{array}{c}-1,025.207 * * * \\
{[0.000]}\end{array}$ & $\begin{array}{c}-1,900.163 * * * \\
{[0.000]}\end{array}$ \\
\hline Strategic & $\begin{array}{l}212.925 \\
{[0.189]}\end{array}$ & $\begin{array}{c}233.378 \\
{[0.807]}\end{array}$ & $\begin{array}{c}138.098^{*} \\
{[0.062]}\end{array}$ & $\begin{array}{c}-196.185 \\
{[0.381]}\end{array}$ \\
\hline Human Rights*Strategic & $\begin{array}{c}4,018.094 * * * \\
{[0.000]}\end{array}$ & $\begin{array}{c}27,957.610 * * * \\
{[0.000]}\end{array}$ & $\begin{array}{c}1,222.180 * * * \\
{[0.000]}\end{array}$ & $\begin{array}{c}3,934.387 \\
{[0.106]}\end{array}$ \\
\hline Priority & $\begin{array}{l}96.777 \\
{[0.169]}\end{array}$ & $\begin{array}{c}1,521.806 * * * \\
{[0.002]}\end{array}$ & $\begin{array}{l}16.251 \\
{[0.585]}\end{array}$ & $\begin{array}{l}131.258 \\
{[0.418]}\end{array}$ \\
\hline Product & $\begin{array}{c}-1,189.013^{* * *} \\
{[0.000]}\end{array}$ & $\begin{array}{c}-9,194.697 * * * \\
{[0.000]}\end{array}$ & $\begin{array}{c}-316.873 * * * \\
{[0.000]}\end{array}$ & $\begin{array}{c}-1,473.999 * * * \\
{[0.000]}\end{array}$ \\
\hline Strategic & $\begin{array}{c}470.216 * * * \\
{[0.001]}\end{array}$ & $\begin{array}{c}4,932.485 * * * \\
{[0.000]}\end{array}$ & $\begin{array}{c}118.587 * * \\
{[0.022]}\end{array}$ & $\begin{array}{c}565.140 * \\
{[0.054]}\end{array}$ \\
\hline Product*Strategic & $\begin{array}{c}1,330.221 * * * \\
{[0.000]}\end{array}$ & $\begin{array}{c}9,672.245 * * * \\
{[0.000]}\end{array}$ & $\begin{array}{c}255.760 * * * \\
{[0.000]}\end{array}$ & $\begin{array}{c}1,053.171 * * \\
{[0.015]}\end{array}$ \\
\hline
\end{tabular}

$* \mathrm{p}<.10, * * \mathrm{p}<.05, * * * \mathrm{p}<.01$ 
Table 6. Strategically prioritized environmental initiatives and CP in ESI vs. non-ESI firms

\begin{tabular}{|c|c|c|c|c|c|c|c|c|}
\hline \multirow[b]{2}{*}{ VARIABLES } & \multicolumn{2}{|c|}{ EBITDA $_{t}$} & \multicolumn{2}{|c|}{ MKT VALUE $_{t}$} & \multicolumn{2}{|c|}{$\mathrm{CAP} \mathrm{EXP}_{t}$} & \multicolumn{2}{|c|}{ INTANG $_{\mathrm{t}}$} \\
\hline & ESI & non ESI & ESI & non ESI & ESI & non ESI & ESI & non ESI \\
\hline Priority & $\begin{array}{c}540.027 * * * \\
{[0.001]}\end{array}$ & $\begin{array}{c}136.963 * * \\
{[0.025]}\end{array}$ & $\begin{array}{c}5,274.267 * * * \\
{[0.000]}\end{array}$ & $\begin{array}{c}1,994.360 * * * \\
{[0.000]}\end{array}$ & $\begin{array}{c}63.669 \\
{[0.420]}\end{array}$ & $\begin{array}{c}44.026 * \\
{[0.056]}\end{array}$ & $\begin{array}{c}1,162.397 * * * \\
{[0.001]}\end{array}$ & $\begin{array}{l}107.438 \\
{[0.385]}\end{array}$ \\
\hline Environment & $\begin{array}{c}-494.591 * * * \\
{[0.004]}\end{array}$ & $\begin{array}{c}-117.651 \\
{[0.350]}\end{array}$ & $\begin{array}{c}896.700 \\
{[0.348]}\end{array}$ & $\begin{array}{c}484.744 \\
{[0.554]}\end{array}$ & $\begin{array}{c}-421.398 * * * \\
{[0.000]}\end{array}$ & $\begin{array}{c}-138.719 * * * \\
{[0.003]}\end{array}$ & $\begin{array}{c}505.554 * \\
{[0.052]}\end{array}$ & $\begin{array}{c}487.663 * * \\
{[0.022]}\end{array}$ \\
\hline Strategic & $\begin{array}{c}799.441 * * * \\
{[0.000]}\end{array}$ & $\begin{array}{c}-352.337 * * * \\
{[0.000]}\end{array}$ & $\begin{array}{c}1,916.978 \\
{[0.190]}\end{array}$ & $\begin{array}{c}-1,485.975^{* *} \\
{[0.041]}\end{array}$ & $\begin{array}{c}594.734 * * * \\
{[0.000]}\end{array}$ & $\begin{array}{c}-104.370 * * * \\
{[0.003]}\end{array}$ & $\begin{array}{c}340.849 \\
{[0.467]}\end{array}$ & $\begin{array}{c}-704.147 * * * \\
{[0.000]}\end{array}$ \\
\hline Environment*Strategic & $\begin{array}{c}620.369 * * * \\
{[0.002]}\end{array}$ & $\begin{array}{c}471.843 * * * \\
{[0.001]}\end{array}$ & $\begin{array}{l}437.207 \\
{[0.760]}\end{array}$ & $\begin{array}{c}1,819.947 * \\
{[0.070]}\end{array}$ & $\begin{array}{c}279.394 * * * \\
{[0.001]}\end{array}$ & $\begin{array}{c}193.510 * * * \\
{[0.000]}\end{array}$ & $\begin{array}{c}-143.940 \\
{[0.770]}\end{array}$ & $\begin{array}{c}76.321 \\
{[0.766]}\end{array}$ \\
\hline Size & YES & YES & YES & YES & YES & YES & YES & YES \\
\hline Industry fixed effects & YES & YES & YES & YES & YES & YES & YES & YES \\
\hline Year fixed effects & YES & YES & YES & YES & YES & YES & YES & YES \\
\hline Constant & YES & YES & YES & YES & YES & YES & YES & YES \\
\hline Observations & 1,953 & 6,957 & 1,953 & 6,957 & 1,953 & 6,957 & 1,953 & 6,957 \\
\hline
\end{tabular}


Table 7. Strategically prioritized CSR initiatives and CP in the pre vs. post crisis period

\begin{tabular}{|c|c|c|c|c|c|c|c|c|}
\hline \multirow[b]{2}{*}{ VARIABLES } & \multicolumn{2}{|c|}{ EBITDA $_{t}$} & \multicolumn{2}{|c|}{ MKT VALUE $_{\mathrm{t}}$} & \multicolumn{2}{|c|}{$\mathrm{CAP} \mathrm{EXP}_{t}$} & \multicolumn{2}{|c|}{ INTANG $_{\mathrm{t}}$} \\
\hline & $2003-2006$ & $2007-2011$ & 2003-2006 & $2007-2011$ & 2003-2006 & 2007-2011 & 2003-2006 & 2007-2011 \\
\hline \multirow[t]{2}{*}{ Priority } & $177.201 * * *$ & 105.711 & $2,292.201 * * *$ & $1,935.488 * * *$ & $51.616^{*}$ & -33.955 & 231.860* & 312.411 \\
\hline & {$[0.006]$} & {$[0.266]$} & {$[0.000]$} & {$[0.001]$} & {$[0.060]$} & {$[0.421]$} & {$[0.068]$} & {$[0.117]$} \\
\hline \multirow[t]{2}{*}{ Community } & -260.634 & -47.096 & 707.141 & 935.139 & $-327.552 * *$ & $-331.301 * *$ & 319.036 & $1,222.471 * * *$ \\
\hline & {$[0.310]$} & {$[0.863]$} & {$[0.663]$} & {$[0.511]$} & {$[0.010]$} & {$[0.018]$} & {$[0.458]$} & {$[0.000]$} \\
\hline \multirow[t]{2}{*}{ Strategic } & 142.309 & -143.192 & $3,404.648 * *$ & -517.670 & -36.707 & -81.120 & 131.122 & -146.056 \\
\hline & {$[0.421]$} & {$[0.428]$} & {$[0.025]$} & {$[0.634]$} & {$[0.601]$} & {$[0.220]$} & {$[0.668]$} & {$[0.746]$} \\
\hline \multirow[t]{2}{*}{ Community*Strategic } & $1,367.595 * * *$ & $1,034.659 * * *$ & $8,179.783 * * *$ & $5,446.470 * * *$ & $638.057 * * *$ & $630.463 * * *$ & $1,119.966 * *$ & 55.715 \\
\hline & {$[0.000]$} & {$[0.002]$} & {$[0.000]$} & {$[0.004]$} & {$[0.000]$} & {$[0.000]$} & {$[0.030]$} & {$[0.927]$} \\
\hline \multirow[t]{2}{*}{ Priority } & $212.940 * *$ & $293.120 * * *$ & $2,951.761 * * *$ & $2,550.543 * * *$ & $89.225 * * *$ & 6.403 & $313.620 * *$ & $472.414 * *$ \\
\hline & {$[0.033]$} & {$[0.000]$} & {$[0.000]$} & {$[0.000]$} & {$[0.001]$} & {$[0.874]$} & {$[0.030]$} & {$[0.032]$} \\
\hline \multirow[t]{2}{*}{ Governance } & -165.087 & -432.549 & $-4,536.377 *$ & $-1,038.675$ & -155.953 & -71.845 & -740.352 & 149.350 \\
\hline & {$[0.390]$} & [0.129] & {$[0.070]$} & {$[0.430]$} & {$[0.160]$} & [0.373] & [0.114] & [0.589] \\
\hline \multirow[t]{2}{*}{ Strategic } & $453.007 * *$ & 428.337 & $3,626.297$ & $2,797.924 *$ & 130.029 & 116.393 & 602.570 & 341.168 \\
\hline & {$[0.032]$} & [0.101] & [0.108] & {$[0.050]$} & [0.203] & [0.209] & [0.157] & [0.289] \\
\hline \multirow[t]{2}{*}{ Governance*Strategic } & $788.467 * * *$ & $929.338 * * *$ & $8,484.828 * * *$ & $5,539.649 * * *$ & $288.089 * * *$ & $243.143 * * *$ & $1,148.894 * *$ & 219.922 \\
\hline & {$[0.001]$} & [0.001] & [0.001] & {$[0.001]$} & {$[0.008]$} & {$[0.005]$} & {$[0.017]$} & {$[0.584]$} \\
\hline \multirow[t]{2}{*}{ Priority } & $295.168 * * *$ & $215.215 * *$ & $3,133.225 * * *$ & $2,436.272 * * *$ & $97.522 * * *$ & 1.245 & $291.062 * *$ & 339.492 \\
\hline & {$[0.000]$} & {$[0.030]$} & {$[0.000]$} & {$[0.000]$} & {$[0.002]$} & [0.977] & {$[0.039]$} & [0.144] \\
\hline \multirow[t]{2}{*}{ Employee } & 14.107 & 12.742 & $1,691.496$ & $1,133.489$ & -43.667 & -105.914 & -397.955 & -391.792 \\
\hline & [0.933] & [0.930] & [0.223] & [0.122] & [0.619] & [0.116] & [0.169] & {$[0.276]$} \\
\hline \multirow[t]{2}{*}{ Strategic } & 214.673 & 141.049 & 472.975 & 9.586 & 97.474 & $108.611^{*}$ & 646.477* & 508.960 \\
\hline & {$[0.277]$} & {$[0.281]$} & {$[0.772]$} & {$[0.990]$} & {$[0.323]$} & {$[0.065]$} & {$[0.056]$} & {$[0.109]$} \\
\hline \multirow[t]{2}{*}{ Employee*Strategic } & $434.498 *$ & $355.957 * *$ & $3,837.006 *$ & $3,717.710 * * *$ & 104.807 & $126.111 *$ & $960.773 * *$ & $745.381 *$ \\
\hline & {$[0.083]$} & {$[0.034]$} & {$[0.056]$} & {$[0.001]$} & [0.334] & {$[0.076]$} & {$[0.023]$} & {$[0.064]$} \\
\hline
\end{tabular}


Table 7 (continued). Strategically prioritized CSR initiatives and CP in the pre vs. post crisis period

\begin{tabular}{|c|c|c|c|c|c|c|c|c|}
\hline \multirow[b]{2}{*}{ VARIABLES } & \multicolumn{2}{|c|}{ EBITDA $_{t}$} & \multicolumn{2}{|c|}{ MKT VALUE $_{\mathrm{t}}$} & \multicolumn{2}{|c|}{$\mathrm{CAP} \mathrm{EXP}_{\mathrm{t}}$} & \multicolumn{2}{|c|}{$\mathrm{INTANG}_{\mathrm{t}}$} \\
\hline & $2003-2006$ & $2007-2011$ & $2003-2006$ & $2007-2011$ & $2003-2006$ & 2007-2011 & $2003-2006$ & $2007-2011$ \\
\hline \multirow[t]{2}{*}{ Priority } & $160.724 * *$ & 123.791 & $2,060.675 * * *$ & $1,991.962 * * *$ & $60.910 * *$ & -12.703 & 138.584 & 351.940 \\
\hline & {$[0.025]$} & {$[0.206]$} & [0.001] & {$[0.002]$} & {$[0.031]$} & {$[0.747]$} & {$[0.355]$} & {$[0.131]$} \\
\hline \multirow[t]{2}{*}{ Product } & $-1,122.421 * * *$ & $-1,156.032 * * *$ & $-10,262.409 * * *$ & $-8,642.471 * * *$ & $-351.862 * * *$ & $-331.468 * * *$ & $-1,732.164 * * *$ & $-1,002.625 * *$ \\
\hline & {$[0.000]$} & {$[0.000]$} & {$[0.000]$} & {$[0.000]$} & {$[0.000]$} & {$[0.000]$} & {$[0.001]$} & {$[0.033]$} \\
\hline \multirow[t]{2}{*}{ Strategic } & $451.512 * *$ & $540.177 * * *$ & $5,242.429 * *$ & $4,988.951 * * *$ & $175.241 * *$ & $171.472 * *$ & 655.826 & 366.802 \\
\hline & {$[0.041]$} & {$[0.002]$} & {$[0.012]$} & {$[0.000]$} & {$[0.050]$} & {$[0.011]$} & {$[0.150]$} & {$[0.314]$} \\
\hline \multirow[t]{2}{*}{ Product*Strategic } & $1,337.657 * * *$ & $1,157.847 * * *$ & $10,954.112 * * *$ & $7,823.269 * * *$ & $271.372 * * *$ & $328.683 * * *$ & $1,835.897 * * *$ & -174.578 \\
\hline & {$[0.000]$} & {$[0.000]$} & {$[0.000]$} & {$[0.000]$} & {$[0.000]$} & {$[0.000]$} & {$[0.000]$} & {$[0.756]$} \\
\hline Size & YES & YES & YES & YES & YES & YES & YES & YES \\
\hline Industry fixed effects & YES & YES & YES & YES & YES & YES & YES & YES \\
\hline Year fixed effects & YES & YES & YES & YES & YES & YES & YES & YES \\
\hline Constant & YES & YES & YES & YES & YES & YES & YES & YES \\
\hline Observations & 4,950 & 3,960 & 4,950 & 3,960 & 4,950 & 3,960 & 4,950 & 3,960 \\
\hline
\end{tabular}


Table 8. Strategically CSR initiatives and CP for prioritizing vs. non-prioritizing firms

\begin{tabular}{|c|c|c|c|c|c|c|c|c|}
\hline \multirow[b]{2}{*}{ VARIABLES } & \multicolumn{2}{|c|}{ EBITDA $_{t}$} & \multicolumn{2}{|c|}{ MKT VALUE $_{\mathrm{t}}$} & \multicolumn{2}{|c|}{$\mathrm{CAP} \mathrm{EXP}_{t}$} & \multicolumn{2}{|c|}{$\mathrm{INTANG}_{\mathrm{t}}$} \\
\hline & Priority & Non Priority & Priority & Non Priority & Priority & Non Priority & Priority & Non Priority \\
\hline Community & $\begin{array}{c}769.358 * * * \\
{[0.010]}\end{array}$ & $\begin{array}{c}-768.531 * * * \\
{[0.001]}\end{array}$ & $\begin{array}{c}7,132.887 * * * \\
{[0.000]}\end{array}$ & $\begin{array}{c}-2,765.448 * * \\
{[0.017]}\end{array}$ & $\begin{array}{l}-25.304 \\
{[0.863]}\end{array}$ & $\begin{array}{c}-445.481 * * * \\
{[0.000]}\end{array}$ & $\begin{array}{c}2,024.053 * * * \\
{[0.000]}\end{array}$ & $\begin{array}{c}238.446 \\
{[0.189]}\end{array}$ \\
\hline Strategic & $\begin{array}{c}-257.925 \\
{[0.245]}\end{array}$ & $\begin{array}{c}201.552 * * \\
{[0.025]}\end{array}$ & $\begin{array}{l}48.396 \\
{[0.977]}\end{array}$ & $\begin{array}{c}1,235.624 * * \\
{[0.026]}\end{array}$ & $\begin{array}{c}-269.995 * * * \\
{[0.001]}\end{array}$ & $\begin{array}{l}-56.614 \\
{[0.233]}\end{array}$ & $\begin{array}{c}-473.034 \\
{[0.370]}\end{array}$ & $\begin{array}{c}354.024 * * \\
{[0.033]}\end{array}$ \\
\hline Community*Strategic & $\begin{array}{l}252.359 \\
{[0.467]} \\
\end{array}$ & $\begin{array}{c}1,369.881 * * * \\
{[0.000]}\end{array}$ & $\begin{array}{c}-683.860 \\
{[0.770]}\end{array}$ & $\begin{array}{c}6,886.916 * * * \\
{[0.000]} \\
\end{array}$ & $\begin{array}{c}340.319 * * \\
{[0.035]}\end{array}$ & $\begin{array}{c}856.135 * * * \\
{[0.000]}\end{array}$ & $\begin{array}{c}-834.440 \\
{[0.245]} \\
\end{array}$ & $\begin{array}{l}450.850 \\
{[0.155]} \\
\end{array}$ \\
\hline Governance & $\begin{array}{c}-121.915 \\
{[0.623]}\end{array}$ & $\begin{array}{c}-271.894 * \\
{[0.077]}\end{array}$ & $\begin{array}{c}-168.583 \\
{[0.928]}\end{array}$ & $\begin{array}{c}-3,231.466 * * * \\
{[0.001]}\end{array}$ & $\begin{array}{l}-76.440 \\
{[0.475]}\end{array}$ & $\begin{array}{c}-1.106 \\
{[0.979]}\end{array}$ & $\begin{array}{c}244.466 \\
{[0.537]}\end{array}$ & $\begin{array}{c}-610.109 * * \\
{[0.032]}\end{array}$ \\
\hline Strategic & $\begin{array}{l}369.449 \\
{[0.216]}\end{array}$ & $\begin{array}{c}264.657 * \\
{[0.056]}\end{array}$ & $\begin{array}{l}47.602 \\
{[0.983]}\end{array}$ & $\begin{array}{c}2,682.333 * * * \\
{[0.003]}\end{array}$ & $\begin{array}{l}108.605 \\
{[0.399]}\end{array}$ & $\begin{array}{l}-17.023 \\
{[0.698]}\end{array}$ & $\begin{array}{c}293.573 \\
{[0.571]}\end{array}$ & $\begin{array}{c}513.442 * * \\
{[0.039]}\end{array}$ \\
\hline Governance* Strategic & $\begin{array}{c}993.669 * * * \\
{[0.002]}\end{array}$ & $\begin{array}{c}595.711 * * * \\
{[0.000]}\end{array}$ & $\begin{array}{c}6,677.533 * * \\
{[0.016]} \\
\end{array}$ & $\begin{array}{c}4,695.395 * * * \\
{[0.000]} \\
\end{array}$ & $\begin{array}{c}275.164 * * \\
{[0.026]}\end{array}$ & $\begin{array}{c}142.152 * * * \\
{[0.003]}\end{array}$ & $\begin{array}{l}43.375 \\
{[0.943]}\end{array}$ & $\begin{array}{c}921.149 * * * \\
{[0.003]}\end{array}$ \\
\hline Employee & $\begin{array}{l}153.862 \\
{[0.280]}\end{array}$ & $\begin{array}{c}-269.749 \\
{[0.116]}\end{array}$ & $\begin{array}{c}2,568.925 * * * \\
{[0.006]}\end{array}$ & $\begin{array}{c}-1,098.411 \\
{[0.139]}\end{array}$ & $\begin{array}{c}19.898 \\
{[0.788]}\end{array}$ & $\begin{array}{c}-175.493 * * \\
{[0.033]}\end{array}$ & $\begin{array}{c}-503.143 \\
{[0.138]}\end{array}$ & $\begin{array}{c}-599.315 \\
{[0.113]}\end{array}$ \\
\hline Strategic & $\begin{array}{l}16.079 \\
{[0.938]}\end{array}$ & $\begin{array}{c}243.553^{*} \\
{[0.070]}\end{array}$ & $\begin{array}{c}-1,057.703 \\
{[0.448]}\end{array}$ & $\begin{array}{l}911.506 \\
{[0.157]}\end{array}$ & $\begin{array}{l}-4.994 \\
{[0.959]}\end{array}$ & $\begin{array}{c}135.497 * * \\
{[0.034]}\end{array}$ & $\begin{array}{l}676.494 \\
{[0.139]}\end{array}$ & $\begin{array}{l}423.918 \\
{[0.146]}\end{array}$ \\
\hline Employee*Strategic & $\begin{array}{c}392.833 * * \\
{[0.044]}\end{array}$ & $\begin{array}{c}311.599 * \\
{[0.076]}\end{array}$ & $\begin{array}{c}4,093.027 * * * \\
{[0.005]}\end{array}$ & $\begin{array}{c}2,526.447 * * * \\
{[0.005]}\end{array}$ & $\begin{array}{c}12.015 \\
{[0.888]}\end{array}$ & $\begin{array}{c}227.312 * * * \\
{[0.006]}\end{array}$ & $\begin{array}{c}1,014.123 * * \\
{[0.021]}\end{array}$ & $\begin{array}{c}622.409 \% \\
{[0.093]}\end{array}$ \\
\hline Size & YES & YES & YES & YES & YES & YES & YES & YES \\
\hline Industry fixed effects & YES & YES & YES & YES & YES & YES & YES & YES \\
\hline Year fixed effects & YES & YES & YES & YES & YES & YES & YES & YES \\
\hline Constant & YES & YES & YES & YES & YES & YES & YES & YES \\
\hline Observations & 4,950 & 3,960 & 4,950 & 3,960 & 4,950 & 3,960 & 4,950 & 3,960 \\
\hline
\end{tabular}

